\title{
Gonadotropin Stimulates Ovarian Renin-Angiotensin System in the Rabbit
}

\author{
Yasunori Yoshimura, " Norihiro Koyama, " Masataka Karube," Takahisa Oda," Masao Akiba, * Akari Yoshinaga, * \\ Shigetatsu Shiokawa, * Masao Jinno, * and Yukio Nakamura * \\ *Department of Obstetrics and Gynecology, Kyorin University School of Medicine, Tokyo, Japan 181; \\ and ${ }^{\ddagger}$ Department of Obstetrics and Gynecology, Tokyo Dental College, Ichikawa General Hospital, Chiba, Japan 272
}

\begin{abstract}
The present study was undertaken to assess the role of ovarian renin-angiotensin system (RAS) in the preovulatory cascade induced by gonadotropin exposure. In the in vitro perfused rabbit ovaries, exposure to human chorionic gonadotropin (hCG) enhanced the secretion rate of angiotensin II (Ang II) within 1 $h$. The secretion rate reached maximal levels at $6 \mathrm{~h}$ and then declined thereafter. The intrafollicular Ang II content and renin-like activity were also significantly increased at 2 and $4 \mathrm{~h}$ after exposure to hCG, compared with control ovaries perfused with medium alone. The level of intrafollicular Ang II after hCG exposure significantly exceeded the concentration of Ang II in an equivalent volume of plasma. The addition of $1 \mu \mathrm{M}$ captopril to the perfusate significantly inhibited the secretion rate of Ang II stimulated by hCG; however, captopril affected neither the ovulatory efficiency nor prostaglandin production in ovaries treated with hCG. Captopril significantly inhibited the resumption of meiosis in the ovulated ova and follicular oocytes stimulated by hCG. The administration of $100 \mu \mathrm{g}$ Ang II at 2-h intervals to the perfusate reversed the inhibitory effects of captopril on hCG-induced oocyte maturation. In conclusion, these data indicate that gonadotropin stimulates renin-like activity and Ang II production in the rabbit ovary. Ovarian renin-angiotensin system may play an important role in the process of oocyte maturation after exposure to gonadotropin. (J. Clin. Invest. 1994. 93:180-187.) Key words: renin-like activity $\bullet$ angiotensin II • ovulation • oocyte maturation • angiotensin I-converting enzyme
\end{abstract}

\section{Introduction}

A functional local renin-angiotensin system (RAS) ${ }^{1}$ is known to exist in the ovary (1-6). Pellicer et al. (7) demonstrated that the intraperitoneal administration of an angiotensin II (Ang II) receptor antagonist, saralasin, blocked ovulation in immature rats that were treated with pregnant mare's serum gonadotropin and human chorionic gonadotropin (hCG). Our previous

Address correspondence to Yasunori Yoshimura, M.D., Department of Obstetrics and Gynecology, Kyorin University School of Medicine, 6-20-2 Shinkawa, Mitaka, Tokyo, Japan 181.

Received for publication 18 May 1993 and in revised form $13 \mathrm{Au}$ gust 1993

1. Abbreviations used in this paper: $\mathrm{ACE}$, angiotensin I-converting enzyme; Ang II, angiotensin II; GVBD, germinal vesicle breakdown; hCG, human chorionic gonadotropin; RAS, renin-angiotensin system.

J. Clin. Invest.

(C) The American Society for Clinical Investigation, Inc.

0021-9738/94/01/0180/08 \$2.00

Volume 93, January 1994, 180-187 study revealed that the addition of Ang II in the perfusate at 2-h intervals induced oocyte maturation and ovulation in the in vitro perfused rabbit ovaries in the absence of gonadotropin, and that the concomitant addition of saralasin completely blocked Ang II-induced ovulation (8). These results indicate that Ang II has a direct role in follicle rupture and oocyte maturation, and they support the hypothesis that Ang II produced in the ovary may act locally in the process of ovulation. An intrinsic RAS in the rabbit ovary may be an intermediary in the gonadotropin-induced ovulation. However, Husain et al. (3) did not find the expected autoradiographic distribution of Ang II receptors in every developing rat follicle, suggesting that not all preovulatory follicles necessarily respond to exogenous or endogenous Ang II. This discrepancy in the effects of Ang II on gonadotropin-induced ovulation impedes a better understanding of the physiological role of Ang II in ovulation.

The finding of higher follicular concentrations of prorenin, renin, and angiotensinogen in humans, and the identification of angiotensinogen and renin messenger RNA in the rat ovary, suggest the presence of a local RAS in the ovary $(1,2,5,9,10)$. The evidence that the ovary secretes prorenin into the follicular fluid and plasma at the time of gonadotropin surge of the normal menstrual cycle $(11,12)$ and after hCG administration to ovarian-stimulated patients (13) further substantiates the hypothesis that the ovarian RAS may play an important role in the function of ovarian follicle. We found that the rates of Ang II secretion were enhanced by gonadotropin in perfused rabbit ovaries, and that the concomitant addition of saralasin inhibited hCG-induced ovulation in a dose-dependent manner (8). Kuo et al. also have demonstrated that Ang II has a direct effect on the rabbit ovary, stimulating both ovulation and oocyte maturation in the absence of gonadotropin (14). These observations point toward a potentially important role of ovarian RAS in the preovulatory cascade induced by gonadotropin exposure, and prompted us to investigate changes in the intrafollicular renin activity and the ovarian secretion rate of Ang II in the process of ovulation. Since local Ang II may be a significant autocrine or paracrine modulator of ovarian function $(7,8$, 14), we also studied the effects of captopril, an angiotensin I-converting enzyme (ACE) inhibitor, on hCG-induced ovulation and oocyte maturation.

\section{Methods}

Animals. Sexually mature female Japanese white rabbits weighing $3.5-$ $4.5 \mathrm{~kg}$, which were cared for according to the guideline of Kyorin University School of Medicine, were isolated for a minimum of $3 \mathrm{wk}$. The rabbits were caged individually and fed water and a diet of Purina rabbit chow (Clea Japan Inc., Tokyo, Japan) ad libitum under conditions of controlled light and temperature. They were anesthetized with intravenous sodium pentobarbital ( $32 \mathrm{mg} / \mathrm{kg}$ ), administered heparin sulfate $(120 \mathrm{U} / \mathrm{kg})$ for anticoagulation, and then subjected to laparotomy. Ovaries were excluded from further study if they appeared immature, or if $\geq 50 \%$ of the surface follicles were hemorrhagic. 
Ovarian perfusion. Although the details of the standard perfusion system have been modified over the years, the basic components have remained constant (15). The ovarian artery and vein were cannulated in situ after ligation of the major anastomotic connections as previously described $(16,17)$. The ovary was removed along with its artery, vein, and supporting adipose tissue, and immediately placed in a perfusion chamber. The perfusion fluid consisted of $150 \mathrm{ml}$ of medium 199 (Gibco Laboratories, Grand Island, NY) containing 1\% BSA (Fraction V powder; Sigma Chemical Co., St. Louis, MO), which was supplemented with heparin sulfate, insulin, streptomycin, and penicillin G, and adjusted to a pH of 7.4. BSA was added to the basic perfusion fluid to increase the oncotic pressure and reduce edema formation (16). Ovaries were observed every $15 \mathrm{~min}$ for evidence of follicle growth and rupture throughout the $12 \mathrm{~h}$ of perfusion.

At the time of follicle rupture, the ovulated ovum surrounded by its cumulus mass was recovered carefully from the ovarian surface with a Pasteur pipette. The time interval between hCG or Ang II administration and follicle rupture was recorded. The ovulatory efficiency (percent of follicles $>1.5 \mathrm{~mm}$ that ovulated) was calculated for each group. At the end of the perfusion, follicular oocytes were recovered by aspiration from mature follicles $>1.5 \mathrm{~mm}$ in diameter. Both the ovulated ova and follicular oocytes were assessed for stage of maturity and signs of degeneration, as previously described (18). Oocytes were placed on slides, fixed in $2.5 \%$ glutaraldehyde, and then stained with $0.25 \%$ lacmoid in $45 \%$ acetic acid for microscopic evaluation. The degree of ovum maturity was expressed as the percentage of ova that achieved germinal vesicle breakdown (GVBD). Ova were also assessed for degenerative changes including vacuolation, cytolysis, necrosis, fragmentation, and loss of spherical shape.

Experimental design. The first experiment using 72 rabbits was undertaken to determine whether the addition of hCG to the perfusate would stimulate the production of Ang II and renin activity in the perfused rabbit ovaries. Both ovaries were perfused with medium alone. 30 min after the onset of perfusion, 50 IU of hCG (CH-446, biological activity $=3,830 \mathrm{IU} / \mathrm{mg}$; Organon, Oss, the Netherlands) was added to the perfusate of one ovary. Ovaries were perfused for $12 \mathrm{~h}$ after hCG administration. Both arterial and venous samples were obtained in six perfused rabbit ovaries before the administration of hCG and $1,2,4,6,8$, and $12 \mathrm{~h}$ thereafter to determine the ovarian secretion rate of Ang II. The perfusate was introduced through the ovarian artery cannula, and was collected from the cannulated ovarian vein and recycled. The ovarian secretion rate of Ang II was calculated by determining the difference in concentrations between the venous and arterial samples as described previously (17). Samples were stored at $-80^{\circ} \mathrm{C}$ until the concentrations of Ang II were determined. The first ovulation in this system using ovarian artery and vein cannulation occurred after $\sim 8 \mathrm{~h}$ of exposure to hCG $(8,17,19)$. The mean time interval from ovulatory stimulus to ovulation has been shown to be $9.51 \pm 0.57 \mathrm{~h}$ after exposure to hCG (17). Therefore, in the experiment for determining the intrafollicular content of Ang II and renin-like activity, ovarian perfusion was terminated before hCG administration and 1, 2, 4, 6, and $8 \mathrm{~h}$ after the exposure to hCG. Six ovaries from six different rabbits were examined at each interval. Mature follicles perfused with or without hCG were immediately excised at each time point of perfusion and stored at $-80^{\circ} \mathrm{C}$ until the intrafollicular Ang II content and renin-like activity were determined. In additional experiments, 30 rabbits received $100 \mathrm{IU}$ of hCG via a marginal ear vein. Preovulatory follicles and venous blood samples were obtained from the same rabbits before $\mathrm{hCG}$ administration and 2, 4, 6, and $8 \mathrm{~h}$ after the exposure to $\mathrm{hCG}$. The blood samples were placed in EDTA-containing tubes and centrifuged. Six ovaries were examined at each interval. The concentrations of Ang II in the preovulatory follicles were compared with those in an equivalent volume of plasma.

In the second experiment using 42 rabbits, one ovary was perfused with $1 \mu \mathrm{M}$ of captopril (Sigma Chemical Co.), an Ang I-converting enzyme inhibitor, while the contralateral ovary that served as a control was perfused simultaneously with medium alone. $30 \mathrm{~min}$ after the onset of perfusion, $50 \mathrm{IU}$ of hCG was added to the perfusate of both ovaries from eight rabbits. Ovarian perfusion was carried out for $12 \mathrm{~h}$ after hCG exposure. Both the arterial and venous samples were obtained at the start of perfusion and $1,2,4,6,8$, and $12 \mathrm{~h}$ thereafter. Samples were stored at $-80^{\circ} \mathrm{C}$ until Ang II concentrations were determined. In the experiment to determine the intrafollicular contents of Ang II in ovaries perfused with hCG alone or hCG plus captopril, ovarian perfusion was terminated before hCG administration and 1, 2, 4,6 , and $8 \mathrm{~h}$ after hCG exposure. At least six ovaries from six different rabbits were examined at each interval. Mature follicles were excised immediately at each time point of perfusion and stored at $-80^{\circ} \mathrm{C}$ until the intrafollicular content of Ang II was determined.

The final experiment was conducted to determine whether the administration of Ang II would reverse the inhibitory effect of captopril on hCG-induced oocyte maturation. Both ovaries from six rabbits were perfused with captopril at a concentration of $1 \mu \mathrm{M}$. 30 min after the onset of perfusion, $50 \mathrm{IU}$ of hCG was added to the perfusate of both ovaries. Our previous study demonstrated that after a single injection of $100 \mu \mathrm{g}$ of Ang II in the presence of the perfused rabbit ovary, the concentration of Ang II in the perfusate decreased as the increasing duration of ovarian perfusion (8), suggesting that Ang II could be metabolized in the perfused rabbit ovaries. In one ovary, therefore, $100 \mu \mathrm{g}$ of Ang II was added to the perfusate every $2 \mathrm{~h}$ for $12 \mathrm{~h}$ of perfusion, while the contralateral ovary was treated with $0.1 \mathrm{ml}$ PBS alone. In another six rabbits, ovaries were perfused with $100 \mu \mathrm{g}$ of Ang II at 2-h intervals or with medium alone in the absence of gonadotropin.

Measurement of Ang II in the follicle, perfusate, and plasma. Perfused rabbit ovaries were removed at $0,1,2,4,6$, and $8 \mathrm{~h}$ after exposure to hCG and placed in ice-cold physiological saline. Mature follicles were isolated under a dissecting microscope. 5-10 follicles were placed in $1 \mathrm{ml}$ ice-cold $20 \mathrm{mM}$ sodium phosphate buffer containing 10,000 $\mathrm{IU} / \mathrm{ml}$ of aprotinin (Sigma Chemical Co.), homogenized (Bio-Mixer; Kenis Scientific Institute, Tokyo, Japan), and then centrifuged at $15,000 \mathrm{~g}$ for $30 \mathrm{~min}$ at $4^{\circ} \mathrm{C}$. The supernatants, perfusate samples, and plasma were stored at $-80^{\circ} \mathrm{C}$ until Ang II concentrations were determined. The extraction of Ang II was performed using the method described by Beadwell (20) with minor modification. After adding ${ }^{125} \mathrm{I}$ Ang II to estimate the recovery rate, the supernatants, perfusate samples, and plasma $(0.1-0.6 \mathrm{ml})$ were suspended in $30 \mathrm{mg}$ florisil to absorb Ang II in the samples. The mixtures were centrifuged at $400 \mathrm{~g}$ for $10 \mathrm{~min}$ and washed twice with $1 \mathrm{ml}$ distilled water. The precipitates were eluted twice with $0.5 \mathrm{~N}$ hydrochloric-acetone solution and centrifuged at $400 \mathrm{~g}$ for $5 \mathrm{~min}$. One milliliter of petroleum ether was added to the supernatant to separate unsubstituted fatty acids. The aqueous extracts were evaporated under a stream of nitrogen gas. The extracts containing Ang II were reconstituted in $500 \mu \mathrm{l}$ of $0.05 \mathrm{M}$ borate buffer ( $\mathrm{pH} 8.5$ ) containing $0.2 \%$ bovine serum albumin, $0.5 \% \mathrm{NaCl}$, and $0.1 \%$ EDTA-2Na. Aliquots of these extracts were used for RIA of Ang II and determination of recovery rates. The average recovery rate for Ang II was $89.5 \%$. The immunoreactivity of Ang II in the perfusate was examined by RIA using ${ }^{125}$ I-Ang II purchased from New England Nuclear Co. (Boston, MA) and rabbit antiserum against an Ang II-BSA conjugate (21). The antiserum cross-reacted as follows: $0.3 \%$ with angioten$\sin \mathrm{I}, 10^{-4} \%$ with [ $\mathrm{Sar}^{1}{ }^{1}-\mathrm{Ala}^{8}$ ] Ang II, 30.8\% with angiotensin III, $46.0 \%$ with des- $\left[\mathrm{Arg}^{1}, \mathrm{Asp}^{2}\right]$ Ang II, and $100 \%$ with [ $\left.\mathrm{Val}^{5}\right]$ Ang II. The standard curve for this assay ranged from 0.75 to $500 \mathrm{pg} /$ tube. The intraand interassay coefficients of variation for Ang II were $11.7 \%$ and $12.9 \%$, respectively.

Measurement of renin-like activity in the follicle. To determine ovarian renin-like activity during the process of ovulation, perfused rabbit ovaries were removed at $0,1,2,4,6,8$, and $12 \mathrm{~h}$ after exposure to hCG. The ovaries were cleaned in ice-cold saline. The mature follicles ( $>1.5 \mathrm{~mm}$ in diameter) were isolated under a dissecting microscope and stored at $-80^{\circ} \mathrm{C}$. On the day of extraction, five frozen follicles were placed in $2 \mathrm{ml}$ ice-cold $20 \mathrm{mM}$ sodium phosphate buffer that contained $1 \mathrm{mM}$ EDTA (Sigma Chemical Co.) and $0.5 \mathrm{mM}$ phenylmethylsulfonyl fluoride (Sigma Chemical Co.) as inhibitors of angiotensinase and angiotensin-converting enzyme, and then homogenized with the Bio-Mixer. The homogenate was clarified by centrifugation at $47,000 \mathrm{~g}$ 
for $30 \mathrm{~min}$ at $4^{\circ} \mathrm{C}$. The supernatant was removed and stored at $-80^{\circ} \mathrm{C}$ until used for estimation of renin-like activity, as previously described (22). Samples were assayed (Gamma Coat [ ${ }^{125}$ I] Renin activity RIA kit; Travenol-Genentech Diagnostics, Cambridge, MA), in which renin-like activity is calculated by measuring the rate of Ang I formation by the putative renin in the sample during in vitro incubation $(5$, 23). The samples were then assayed in duplicate for Ang I. The assay sensitivity was $0.3 \mathrm{ng} / \mathrm{mg}$ per $\mathrm{h}$ Ang I. The intra- and interassay coefficients of variation for renin-like activity were 9.4 and $12.8 \%$, respectively.

RIA for prostaglandin. PG was extracted as previously described (24). The average recovery rates of $\mathrm{PGF}_{2 \alpha}$ and $\mathrm{PGE}_{2}$ were 79.4 and 84.8\%, respectively. The concentrations of $\mathrm{PGF}_{2 \alpha}$ and $\mathrm{PGE}_{2}$ were measured by RIA kits supplied by Amersham International (Amersham, United Kingdom). $\mathrm{PGF}_{2 \alpha}$ and $\mathrm{PGE}_{2}$ antibodies cross-reacted $2 \%$ with other closely related PGs. Intra- and interassay coefficients of variation were $8.2 \%$ and $9.8 \%$, respectively, for $\mathrm{PGF}_{2 \alpha}$, and $7.6 \%$ and $9.2 \%$, respectively, for $\mathrm{PGE}_{2}$. The sensitivities of the assay for $\mathrm{PGF}_{2 \alpha}$ and $\mathrm{PGE}_{2}$ were $3 \mathrm{pg} /$ tube and $43 \mathrm{pg} /$ tube, respectively.

Statistical analysis. Data regarding the numbers of ovulation per ovary, ovulatory efficiency, time of ovulation, percentages of GVBD and degeneration, concentration of Ang II, and renin activity are represented as the mean \pm SEM. To obtain a normal distribution, data regarding ovulatory efficiency, percentages of GVBD and degeneration were transformed using arcsin transformation. Statistical analysis was performed by ANOVA with Scheffe's test. Differences were considered significantly if $P<0.05$.

\section{Results}

The ovarian secretion rate of Ang II in the in vitro perfused rabbit ovaries, which was calculated by determining the difference in concentrations between the venous and arterial samples, was undetectable in the unstimulated control ovaries during the entire perfusion period (Fig. 1). Exposure to hCG enhanced the secretion of Ang II in perfused rabbit ovaries within $1 \mathrm{~h}$. The maximal secretion of Ang II $(74 \pm 12 \mathrm{pg} / \mathrm{min}$ per ovary) occurred at $6 \mathrm{~h}$ and declined thereafter. The intrafollicular renin activity was $3.96 \pm 0.58 \mathrm{ng} / \mathrm{mg}$ per $\mathrm{h}$ in unstimu-

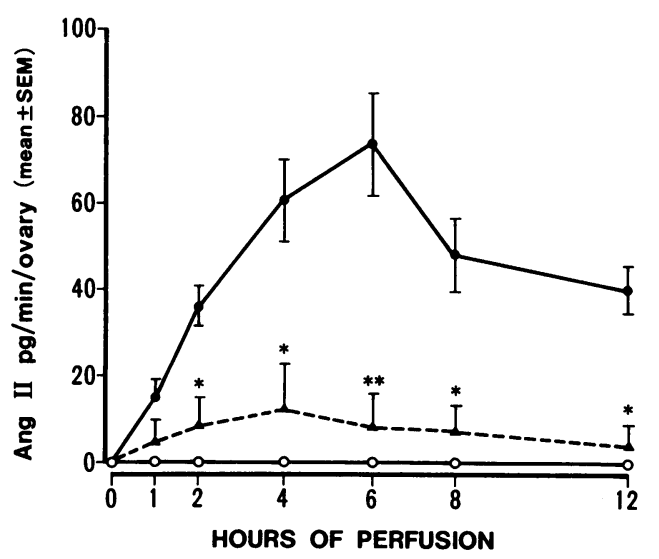

Figure 1. Angiotensin II secretion by perfused rabbit ovaries. Rabbit ovaries were perfused with medium alone $(\circ-0), 50 \mathrm{IU}$ of hCG $(\bullet)$, or with $50 \mathrm{IU}$ of hCG plus $1 \mu \mathrm{M}$ of captopril $(\llcorner--\rightarrow$ ) Ovarian secretion rate $(\mathrm{pg} / \mathrm{min}$ per ovary) was calculated by determining the difference in concentrations between venous and arterial samples. Data points regarding hCG-treated ovaries represent the mean \pm SEM of at least six perfused rabbit ovaries. Values with asterisks differed significantly from values in ovaries perfused with hCG alone; ${ }^{*} P<0.05 ;{ }^{*} P<0.01$. lated ovaries and did not change substantially during the $12 \mathrm{~h}$ of perfusion. In hCG-treated ovaries, the intrafollicular reninlike activity began to increase within $1 \mathrm{~h}$ after exposure to $\mathrm{hCG}$ (Fig. 2). By $4 \mathrm{~h}$ after hCG administration, the intrafollicular renin-like activity increased approximately twofold $(P<0.01)$ to $8.27 \pm 0.42 \mathrm{ng} / \mathrm{mg}$ per $\mathrm{h}$ and returned to pretreatment levels in $8 \mathrm{~h}$. Similar to the alteration of intrafollicular renin-like activity, the intrafollicular content of Ang II significantly increased $2 \mathrm{~h}$ after exposure to hCG, reached a maximum of $4 \mathrm{~h}$, and thereafter declined (Fig. 3 ). The intrafollicular renin activity and Ang II content were significantly increased at 2 and $4 \mathrm{~h}$ after exposure to hCG, compared with values in control ovaries perfused with medium alone. The level of Ang II in the mature follicle exceeded its concentration in the plasma by 10 - to 60 fold (Fig. 4). The peripheral Ang II concentration did not change substantially during the process of ovulation after gonadotropin exposure, unlike the intrafollicular content of Ang II.

Ovulation occurred in all ovaries treated with hCG alone or with hCG plus captopril at a concentration of $1 \mu \mathrm{M}$, while any ovaries perfused with medium alone or captopril failed to ovulate in the absence of gonadotropin (Table I). The mean number of ovulations per ovary and ovulatory efficiency were reduced in the ovaries that were perfused with captopril, as compared with the hCG-treated control; however, these differences were not significant. Additionally, the time of ovulation in the captopril-treated and control ovaries did not differ significantly.

The addition of captopril to the perfusate significantly inhibited the secretion rate of Ang II in ovaries stimulated by hCG during the entire period of perfusion (Fig. 1). Furthermore, the intrafollicular Ang II content was significantly reduced in captopril-treated ovaries beginning at $2 \mathrm{~h}$ after exposure to hCG (Fig. 3). The concentrations of intrafollicular Ang II in ovaries perfused with hCG plus captopril did not differ significantly from control ovaries perfused with medium alone. Although the addition of captopril to the perfusate increased

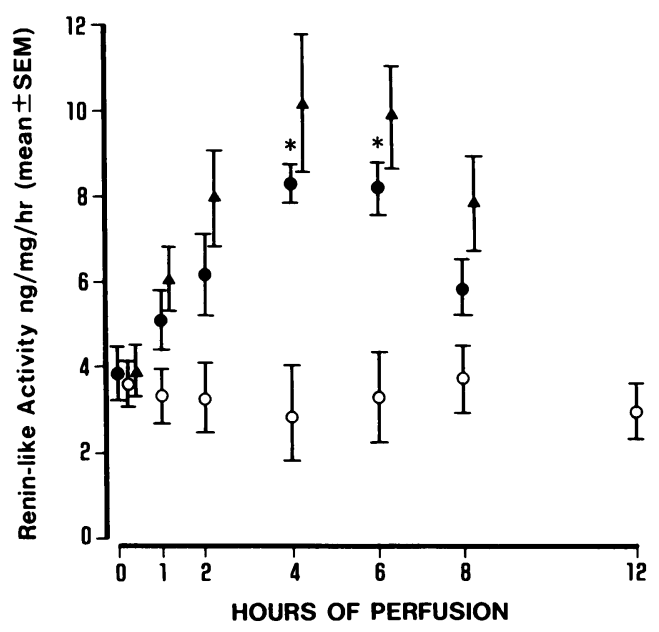

Figure 2. Changes in intrafollicular renin activity after hCG administration. Rabbit ovaries were perfused with medium alone (o), or 50 IU of hCG ( $\bullet$ ), or $50 \mathrm{IU}$ of hCG plus $1 \mu \mathrm{M}$ of captopril ( $\Delta$ ). Ovarian perfusion was terminated before hCG administration and 1, 2, 4, 6, and $8 \mathrm{~h}$ after $\mathrm{hCG}$ exposure. Data points represent the mean \pm SEM of six ovaries from six different rabbits. Values with asterisks differed significantly from values in unstimulated ovaries; ${ }^{*} P<0.01$. 


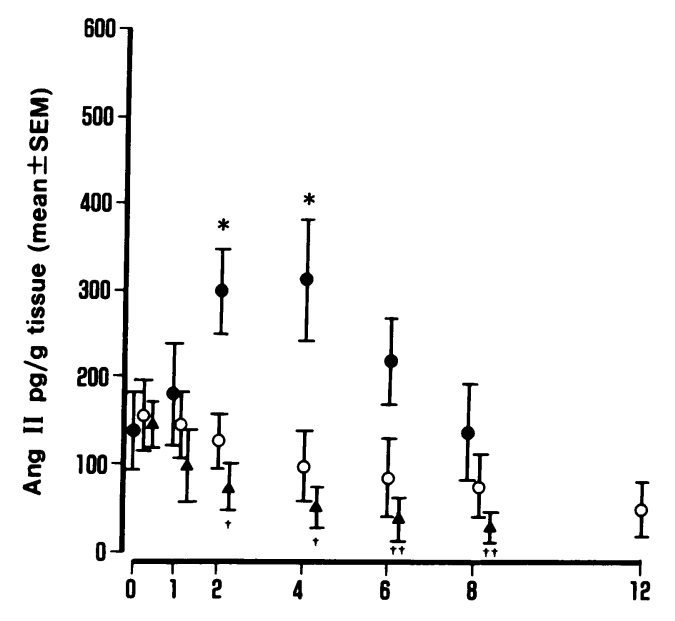

Figure 3. Changes in intrafollicular angiotensin II contents after hCG administration. Rabbit ovaries were perfused with medium alone $(0), 50 \mathrm{IU}$ of hCG $(\bullet)$, or $50 \mathrm{IU}$ of hCG plus $1 \mu \mathrm{M}$ of captopril ( $\triangle$ ). Ovarian perfusion was terminated before $\mathrm{hCG}$ administration and $1,2,4,6$, and $8 \mathrm{~h}$ after hCG exposure. Data points represent the mean \pm SEM of at least six ovaries from six different rabbits. Values with asterisks differed significantly from values in unstimulated ovaries; ${ }^{*} P<0.05$. Values with daggers differed significantly from values in ovaries perfused with hCG alone; ${ }^{\dagger} P<0.01 ;{ }^{\dagger \dagger} P<0.05$.

the intrafollicular renin-like activity in the hCG-treated ovaries, the difference was not significant (Fig. 2). The secretion rates of $\mathrm{PGE}_{2}$ and $\mathrm{PGF}_{2 \alpha}$ in ovaries perfused with medium alone were very low throughout the entire period of perfusion (Fig. 5). Adding hCG to the perfusate significantly increased the production of $\mathrm{PGE}_{2}$ and $\mathrm{PGF}_{2 \alpha}$ at 6,8 , and $12 \mathrm{~h}$ after exposure to hCG and at 6 and $8 \mathrm{~h}$ after exposure to hCG, respectively. However, $1 \mu \mathrm{M}$ captopril did not significantly inhibit the hCG-stimulated production of $\mathrm{PGE}_{2}$ and $\mathrm{PGF}_{2 \alpha}$ by perfused rabbit ovaries.

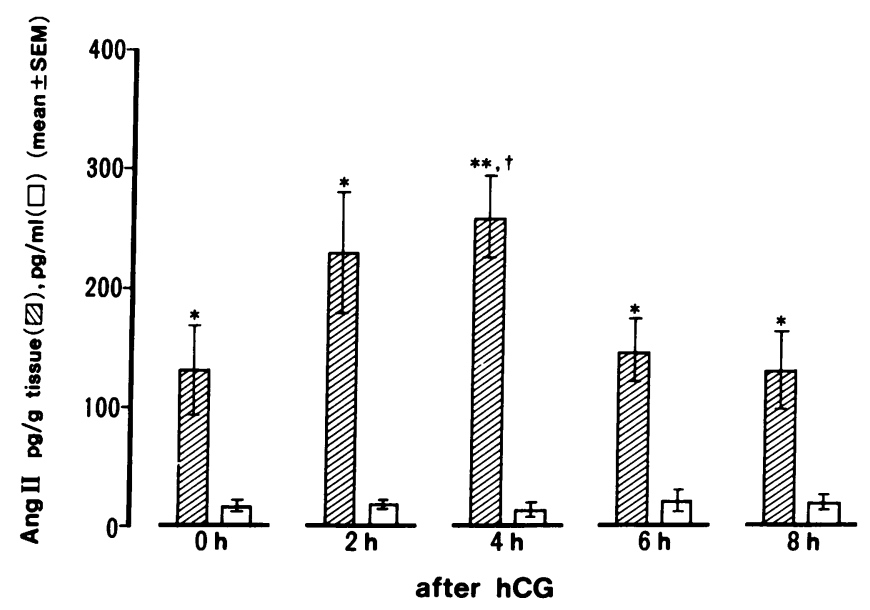

Figure 4. Changes in angiotensin II in the preovulatory follicle ( and plasma ( $\square$ ) in rabbits after in vivo exposure to hCG. Rabbits received $100 \mathrm{IU}$ of hCG via the marginal ear vein. Preovulatory follicles and plasma were obtained before hCG administration and 2, 4, 6 , and $8 \mathrm{~h}$ after hCG exposure. Data represent the mean \pm SEM of six rabbits. Values with asterisks differed significantly from values in an equivalent volume of plasma; ${ }^{*} P<0.01 ;{ }^{* *} P<0.001$. Values with dagger differed significantly from values in follicles before hCG administration; ${ }^{\dagger} P<0.05$.
Table I. Effects of Captopril on hCG-induced Ovulation

\begin{tabular}{lcccc}
\hline & $\begin{array}{c}\text { hCG } \\
(50 \mathrm{IU})\end{array}$ & $\begin{array}{c}\text { hCG }(50 \mathrm{IU}) \\
+ \text { captopril } \\
(1 \mu \mathrm{M})\end{array}$ & $\begin{array}{c}\text { Captopril } \\
(1 \mu \mathrm{M})\end{array}$ & $\begin{array}{c}\text { Medium } \\
\text { alone }\end{array}$ \\
\hline $\begin{array}{c}\text { Number of ovaries } \\
\text { perfused }\end{array}$ & 8 & 8 & 6 & 6 \\
$\begin{array}{c}\text { Number of ovaries } \\
\text { ovulating }\end{array}$ & 8 & 8 & 0 & 0 \\
$\begin{array}{c}\text { Number of ovulation } \\
\text { per ovary }\end{array}$ & $5.00 \pm 0.53$ & $4.56 \pm 0.44$ & - & - \\
$\begin{array}{c}\text { Ovulatory efficiency } \\
(\%)\end{array}$ & $80.7 \pm 5.2$ & $66.7 \pm 3.2$ & - & - \\
$\begin{array}{c}\text { Time of ovulation } \\
(\mathrm{h})\end{array}$ & $9.31 \pm 0.58$ & $8.74 \pm 0.39$ & - & - \\
\hline
\end{tabular}

* Percentage of mature follicles that proceeded to rupture during perfusion.

The majority of ovulated ova and follicular oocytes resumed meiotic maturation in response to hCG exposure during perfusion (Fig. 6). The concomitant addition of captopril in a concentration of $1 \mu \mathrm{M}$ significantly inhibited the resumption of meiosis in the ovulated ova and follicular oocytes in ovaries perfused with hCG. However, examination of the ovulated ova and follicular oocytes for evidence of degeneration revealed no significant differences between two groups. The
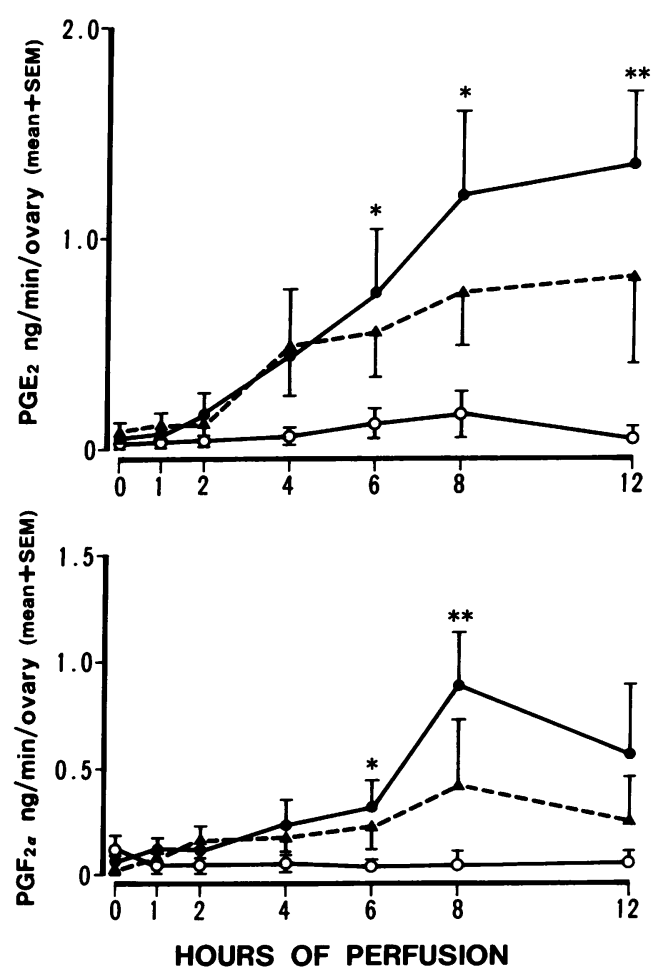

Figure 5. Effects of captopril on the secretion rates of $\mathrm{PGE}_{2}$ and $\mathrm{PGF}_{2 \alpha}$ in perfused rabbit ovaries. Rabbit ovaries were perfused with medium alone $(\circ-0), 50 \mathrm{IU}$ of hCG $(\bullet)$ ), or $50 \mathrm{IU}$ of hCG plus $1 \mu \mathrm{M}$ of captopril $(\llcorner---\Delta)$. Data points represent the mean \pm SEM of at least six ovaries from six different rabbits. Values with asterisks differed significantly from values in ovaries treated with medium alone; ${ }^{*} P<0.05 ;{ }^{* *} P<0.01$. 


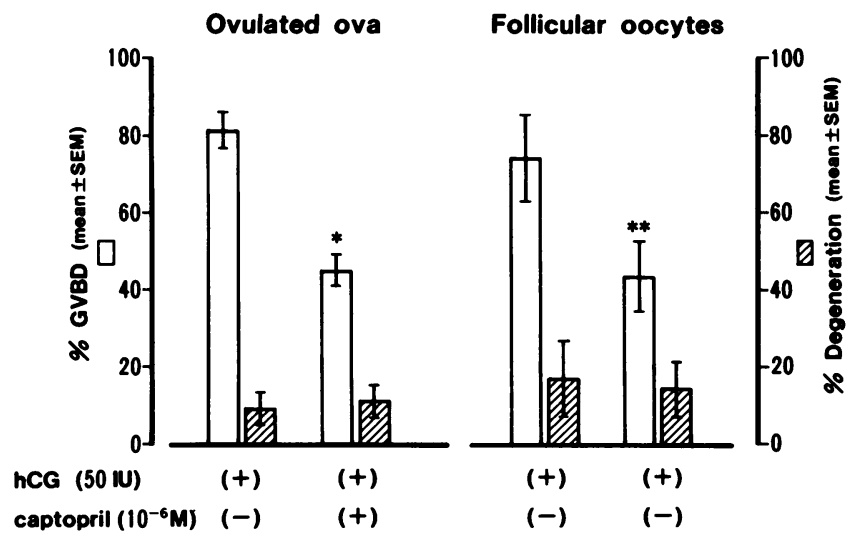

Figure 6. Effects of captopril on hCG-induced oocyte maturation and degeneration. One ovary was perfused with $1 \mu \mathrm{M}$ of captopril, while the contralateral ovary, which served as a control, was perfused simultaneously with medium alone. 30 min after the onset of perfusion, $50 \mathrm{IU}$ of hCG was added to the perfusate of both ovaries. Data represent the mean \pm SEM of eight ovaries from eight different rabbits. Values with asterisks differed significantly from values in ovaries treated with hCG alone. ${ }^{*} P<0.001 ;{ }^{* *} P<0.05$.

administration of $100 \mu \mathrm{g}$ of Ang II at 2-h intervals to the perfusate significantly stimulated the meiotic maturation of the ovulated ova and follicular oocytes in the absence of gonadotropin (Table II). Additionally, Ang II reversed the inhibitory effects of captopril on hCG-induced oocyte maturation.

\section{Discussion}

Local extrarenal RAS have been implicated in the paracrine or autocrine control of hormone production. The local systems have been identified in several organs, including the adrenal

Table II. Ovulation and Oocyte Maturation in hCG-treated Ovaries Perfused with Captopril or with Captopril Plus Ang II, or in Ovaries Perfused with Ang II or with Medium Alone

\begin{tabular}{lcccc}
\hline & \multicolumn{2}{c}{ hCG-treated ovaries } & & \\
\cline { 2 - 4 } & $\begin{array}{c}\text { Captopril } \\
(1 \mu \mathrm{M})\end{array}$ & $\begin{array}{c}\text { Captopril } \\
+ \text { Ang II } \\
(100 \mu \mathrm{g} / 2 \mathrm{~h})\end{array}$ & $\begin{array}{c}\text { Ang II } \\
(100 \mu \mathrm{g} / 2 \mathrm{~h})\end{array}$ & $\begin{array}{c}\text { Medium } \\
\text { alone }\end{array}$ \\
\hline $\begin{array}{c}\text { Number of ovaries } \\
\text { perfused }\end{array}$ & 6 & 6 & 6 & 6 \\
$\begin{array}{c}\text { Number of ovaries } \\
\text { ovulating }\end{array}$ & 6 & 6 & 6 & 0 \\
$\begin{array}{c}\text { Ovulatory efficiency } \\
(\%)^{*}\end{array}$ & $60.3 \pm 4.6$ & $70.2 \pm 4.0$ & $42.5 \pm 5.8$ & - \\
$\begin{array}{c}\text { GVBD }(\%)^{\ddagger} \\
\text { Ovulated ova }\end{array}$ & $33.1 \pm 4.2$ & $70.5 \pm 3.0^{\S}$ & $48.6 \pm 5.5$ & - \\
$\quad$ Follicular oocytes & $27.8 \pm 9.3$ & $66.7 \pm 10.5^{\prime \prime}$ & $44.2 \pm 7.7$ & $5.7 \pm 2.6$ \\
\hline
\end{tabular}

* Percentage of mature follicles that proceeded to rupture during perfusion. ${ }^{\ddagger}$ Percentage of ovulated ova and follicular oocytes that achieved GVBD. ${ }^{\S} P<0.001 ; " ~ P P<0.05$ when compared with ovaries perfused with captopril alone. gland, Leydig cells, hypothalamus, and pituitary gland (2528 ). The present study demonstrates that exposure to hCG enhanced the secretion rate of Ang II in the perfused rabbit ovaries. Additionally, the intrafollicular content of Ang II and renin-like activity were significantly stimulated by the administration of hCG, compared with values in control ovaries perfused with medium alone. The assay used to measure reninlike activity depends upon the cleavage of Ang I from the renin substrate, and the product is measured by a specific RIA for Ang I. The presence of renin-like activity in the mature follicles is not necessarily caused by "true" renin activity because other mechanisms that include cleavage by acid proteases to furnish Ang I have been described elsewhere $(23,29)$. The level of intrafollicular Ang II in the rabbit ovaries after exposure to hCG significantly exceeded that found in an equivalent volume of plasma, suggesting a local production of Ang II in preovulatory follicles. The elevation in the intrafollicular reninlike activity, which appeared to be triggered by the preovulatory rise of gonadotropin, may yield an increase in ovarian secretion and biosynthesis of Ang II. The preovulatory rise in components of ovarian RAS suggest a possible role for ovarian RAS in the ovulatory process. These data, together with other information showing that the increase in human plasma prorenin concentration occurs almost exactly at the time of ovulation $(1,11)$, and that gonadotropin stimulates renin activity and Ang II immunoreactivity in follicular fluid (5), support the existence in the ovary of an intrinsic RAS, which is responsible as an intermediary of gonadotropin-induced ovulation. However, the elevation in the intrafollicular renin-like activity and Ang II in the in vitro perfused rabbit ovaries does not mean that either active renin or Ang II is normally present in these concentrations in vivo, since inadvertent activation of prorenin can occur in vitro (29). Therefore, one cannot exclude the possibility that the intrafollicular serine proteases, which are produced by follicular cells after gonadotropin surge $(19,30$, 31 ), may stimulate the generation of Ang II in the preovulatory follicles by activation of prorenin to renin and/or by the direct cleavage of angiotensinogen.

Autoradiographic studies $(3,32,33)$ revealed a lack of Ang II receptors in preovulatory follicles containing the luteinizing hormone receptor, suggesting that not all preovulatory follicles respond necessarily to exogenous or endogenous Ang II. In a previous study from our laboratory, $100 \mu \mathrm{g}$ of Ang II at 2-h intervals induced ovulation in all ovaries in the absence of gonadotropin, but ovulatory efficiency was significantly lower than in the hCG-treated ovaries (8). Furthermore, the addition of saralasin, a specific receptor antagonist of Ang II, to the perfusate blocked the hCG-induced ovulation in the perfused rabbit ovaries in a dose-dependent manner (8). However, saralasin did not completely block hCG-induced ovulation. This implies that other components within the preovulatory follicular environment than ovarian RAS may also be required for follicles to rupture. Alternatively, the failure of Ang II to induce ovulation with an efficiency comparable to that of hCG implies that the response of preovulatory follicles to Ang II leading to ovulation can be attributed to the functional heterogeneity of follicles within the ovary. The present study demonstrated that gonadotropin stimulated the renin activity and Ang II content in the preovulatory follicles and the production of Ang II by the perfused rabbit ovaries. In addition to the presence in the ovary of all components of RAS, the ovary has been shown to contain 
angiotensinogen and renin messenger RNA $(9,10)$. These results indicate that all reactions leading to Ang II formation can potentially occur in ovarian cells resulting in follicle rupture.

Several classes of potent and specific nonpeptide inhibitors have been synthesized in an effort to produce active ACE inhibitors that could be useful as antihypertensive agents (34). Captopril is thought to bind the active site of ACE in a manner analogous to endogenous substrates, and has been widely used in experiments designed to define the biological function of ACE (35-38). The addition of captopril to the perfusate did not inhibit hCG-induced ovulation, despite significant reductions in both the intrafollicular Ang II content and the secretion rate of Ang II in ovaries perfused with hCG. These findings are in accordance with data showing that short and long term infusions of captopril in immature rats, in which ovulation was induced by sequential treatment with pregnant mare's serum gonadotropin and hCG, did not significantly affect ovulation compared with that in vehicle-infused control rats (37). Our previous study demonstrated that saralasin, an Ang II receptor antagonist, significantly inhibited hCG-induced ovulation in the experiment using the same procedure and animals (8). Although this discrepancy between the results with captopril and saralasin remains to be explained, the use of ACE inhibitors as reagents to assess the function of RAS has been criticized on the basis that at least some of these compounds have additional effects, including the prevention of the hydrolysis of bradykinin (34). One possibility is that a decrease in the levels of ACE in the preovulatory follicles by captopril administration may allow a rise in intrafollicular levels of bradykinin, since ACE degrades bradykinin $(34,39)$. Bradykinin, a physiological substrate for ACE, has been shown to be obligatory for ovulation in the perfused rabbit ovary (40). The present findings showing a lack of antiovulatory response of captopril may depend on the relative increased levels of bradykinin in the preovulatory follicles. Daud et al. demonstrated that rat follicles containing high levels of ACE on their granulosa cells are exclusively developing or atretic (37). Another possibility is that ACE inhibition by captopril apparently does not modify the normal ovulatory process induced by gonadotropin exposure, since ACE levels are markedly reduced in preovulatory follicles (37). Clearly, additional experiments with selective antagonists of ACE are needed to assess the role of intraovarian Ang II in the process of ovulation.

Growing evidence suggests that PGs may be involved in the process of ovulation via local actions at the level of the ovary (41-44). We recently found that the inhibition of Ang IIstimulated PG production by indomethacin led to the complete blockade of Ang II-induced ovulation (unpublished observations). Furthermore, exposure to saralasin inhibited hCG-stimulated PG production in a dose-dependent manner, concomitant with the blockade of ovulation. This implies that Ang II induces ovulation in the rabbit ovary, at least in part, by a mechanism that depends on a stimulatory effect of Ang II on PG production. In the present study, captopril significantly inhibited both the hCG-stimulated secretion rate of Ang II and intrafollicular content of Ang II, but did not reduce PG production by perfused rabbit ovaries. The ovarian biosynthesis of $P G$ did not differ significantly between hCG- and hCG plus captopril-treated ovaries despite a significant inhibition of Ang II production in the ovaries treated with captopril. These observations argue against the hypothesis that Ang II plays an inter- mediary role in the preovulatory cascade induced by gonadotropin exposure.

It has been reported that the treatment of cultured endometrial decidual cells with enalaprilat, an another ACE inhibitor, inhibits the production of $\mathrm{PGE}_{2}$ in a dose-dependent manner, but that the concurrent administration of Ang II does not reverse the inhibitory effect of enalaprilat (38). Although the reasons underlying the apparent discrepancies between the present findings and other study remain to be clarified, there are several possible explanations for the failure of captopril to inhibit PG production in rabbit ovaries, including subtle differences in the experimental conditions involved and in the responsiveness of the tissues used to ACE inhibitors. Squires and Kennedy (38) demonstrated that $10^{-5}-10^{-7} \mathrm{M}$ enalaprilat inhibited PG production by endometrial stromal cells, suggesting that the dose of captopril used in the present study was not too small to be effective. In fact, $1 \mu \mathrm{m}$ captopril significantly inhibited the secretion rate and intrafollicular content of Ang II stimulated by hCG exposure. Some of the effects of ACE inhibitors on PG production may result from their ability to inhibit the enzymatic destruction of bradykinin or to affect other responses unrelated to the RAS (34). Bradykinin promotes PG biosynthesis by selectively activating phospholipase $A_{2}$, liberating arachidonic acid for conversion to $\mathrm{PGs}$ by cyclooxygenase and endoperoxidase isomerases and reductases (45-47). Our previous study also revealed that bradykinin significantly stimulated the production of PG by perfused rabbit ovaries (40). The relatively high levels of bradykinin in the ovaries treated with the ACE inhibitor may compensate for the reduction in PG production by ovaries in reduced levels of Ang II, and thus did not block the normal ovulatory response. Further study is needed to assess the relative contributions of bradykinin and of the blockade of Ang II production to the effects of ACE inhibitors on the ovarian RAS.

In the previous study from our laboratory, Ang II stimulated significantly the meiotic maturation of ovulated ova and follicular oocytes in the absence of gonadotropin stimulus (8). Furthermore, the concomitant addition of saralasin at $2 \times 10^{-6}$ $M$ inhibited significantly hCG-induced oocyte maturation. In contrast, Kuo et al. (14) demonstrated using the same rabbit ovary perfusion system that Ang II did not play a critical role in the meiotic maturation. The discrepancies between our findings and other study may be caused by the differences in the doses of saralasin used and in the administration method of Ang II. Indeed, the inhibitory effect of saralasin on hCG induced oocyte maturation was less effective than that of captopril. The present study demonstrated that the inhibition of endogenous ACE by captopril significantly blocked the meiotic maturation of ovulated ova and follicular oocyte stimulated by exposure to hCG. Thus, as has been described for the role of Ang II in the ovulatory process $(7,8,14)$, locally produced Ang II in the ovary may be a centerpiece of an intraovarian regulatory loop leading to the promotion of key preovulatory events. Furthermore, the addition of Ang II to the perfusate reversed the inhibitory effects of captopril on the hCG-induced oocyte maturation, ruling out the possibility that the inhibitory effect of captopril is not caused by a nonspecific action. These data imply that the generation of Ang II by ACE within the preovulatory follicles plays an important intermediary role after exposure to the gonadotropin surge. Ang II has been also shown to promote progesterone-induced maturation in oocytes from 
Xenopus laevis by mobilizing $\mathrm{Ca}^{2+}$ via a signal transferred through the gap junctions between the follicular cells and the oocyte (48). Recent data derived from the in vitro fertilization program in humans demonstrate that the prorenin concentration in the follicular fluid is correlated with follicular development, oocyte-cumulus complex maturity, and oocyte viability, resulting in successful pregnancy $(49,50)$. These observations, in conjunction with data showing the immunolocalization of angiotensin converting enzyme in the rabbit oolemma (51), suggest that the ovarian RAS may be involved in the process of maturation of mammalian oocyte as well. The clinical use of ACE inhibitors in hypertensive women who seek to become pregnant may inhibit oocyte maturation in the normal ovulatory process, suggesting that these analogues would be contraindicated in such cases.

In conclusion, Ang II was synthesized and secreted by mature ovarian follicles of the rabbit in response to gonadotropin exposure. The addition of captopril to the perfusate significantly inhibited hCG-induced oocyte maturation, but not ovulation. These results suggest that the ovarian RAS may play an important role in the process of oocyte maturation after gonadotropin exposure. Further studies to elucidate the function of the ovarian RAS may have relevance to many aspects of reproductive physiology in mammals.

\section{References}

1. Glorioso, N., S. A. Atlas, J. H. Laragh, R. Jewelewicz, and J. E. Sealey. 1984. Prorenin in high concentrations in human ovarian follicular fluid. Science (Wash. DC) 233:1422-1424.

2. Culler, M. D., B. C. Tarlatzis, L. A. Fernandez, A. H. DeCherney, A. Negro-Vilar, and F. Naftolin. 1986. Angiotensin II-like immunoreactivity in human ovarian follicular fluid. J. Clin. Endocrinol. Metab. 62:613-615.

3. Husain, A., F. M. Bumpus, P. DeSilva, and R. C. Speth. 1987. Localization of angiotensin II receptors in ovarian follicles and the identification of angiotensin II in rat ovaries. Proc. Natl. Acad. Sci. USA. 84:2489-2493.

4. Pucell, A. G., F. M. Bumpus, and A. Husain. 1987. Rat ovarian angiotensin II receptors. J. Biol. Chem. 262:7076-7080.

5. Lightman, A., B. C. Tarlatzis, P. J. Rzasa, M. D. Cellular, V. J. Caride, A. F. Negro-Vilar, D. Lennard, A. H. DeCherney, and F. Naftolin. 1987. The ovarian renin-angiotensin system: renin-like activity and angiotensin II/III immunoreactivity in gonadotropin-stimulated and unstimulated human follicular fluid. $\mathrm{Am}$. J. Obstet. Gynecol. 156:808-816.

6. Speth, R. C., and A. Husain. 1988. Distribution of angiotensin-converting enzyme and angiotensin II-receptor binding sites in the rat ovary. Biol. Reprod. 38:695-702.

7. Pellicer, A., A. Palumbo, A. H. DeCherney, and F. Naftolin. 1988. Blockade of ovulation by an angiotensin antagonist. Science (Wash. DC) 240:16601661 .

8. Yoshimura, Y., M. Karube, N., Koyama, S. Siokawa, T. Nanno, and Y. Nakamura. 1992. Angiotensin II directly induces follicle rupture and oocyte maturation in the rabbit. FEBS (Fed. Eur. Biochem. Soc.) Lett. 307:305-308.

9. Ohkubo, H., K. Nakayama, T. Tanaka, and S. Nakanishi. 1986. Tissue distribution of rat angiotensinogen mRNA and structural analysis of its heterogeneity. J. Biol. Chem. 261:319-323.

10. Kim, S. J., M. Sinjo, A. Fukamizu, H. Miyasaki, S. Usuki, and K. Murakami. 1987. Identification of renin and renin messenger RNA sequence in rat ovary and uterus. Biochem. Biophys. Res. Commun. 142:169-175.

11. Sealey, J. E., S. A. Atlas, N. Glorioso, H. Manapat, and J. H. Laragh. 1985. Cyclical secretion of prorenin during the menstrual cycle: synchronization with luteinizing hormone and progesterone. Proc. Natl. Acad. Sci. USA. 82:87058709.

12. Sealey, J. E., I. Cholst, N. Glorioso, C. Troffa, I. D. Weintraub, G. James, and J. H. Laragh. 1987. Sequential changes in plasma luteinizing hormone and plasma prorenin during the menstrual cycle. J. Clin. Endocrinol. Metab. 63:1-5.

13. Itskovitz, J., J. E. Sealey, N. Glorioso, and Z. Rosenwaks. 1987. Plasma prorenin response to hCG in ovarian hyperstimulated women: correlation with the number of ovarian follicles and steroid hormone concentrations. Proc. Natl. Acad. Sci. USA. 84:7285-7289.
14. Kuo, T.-C., K. Endo, A. M. Dharmarajan, T. Miyazaki, S. J. Atalas, and E. E. Wallach. 1991. Direct effect of angiotensin II on in-vitro perfused rabbit ovary. J. Reprod. Fertil. 92:469-474.

15. Kobayashi, Y., K. H. Wright, R. Santulli, and E. E. Wallach. 1981. Ovulation and ovum maturation in the rabbit ovary perfused in vitro. Biol. Reprod. 24:483-490.

16. Dharmarajan, A. M., Y. Yoshimura, K. Sueoka, S. J. Atlas, N. H. Dubin, L. L. Ewing, B. R. Zirkin, and E. E. Wallach. 1988. Progesterone secretion by corpora lutea of the isolated perfused rabbit ovary during pseudopregnancy. Biol. Reprod. 38:1137-1143.

17. Yoshimura, Y., Y. Nakamura, M. Shiraki, Y. Hirota, H. Yamada, M. Ando, Y. Ubukata, and M. Suzuki. 1991. Involvement of leukotriene $\mathrm{B}_{4}$ in ovulation in the rabbit. Endocrinology. 129:193-199.

18. Yoshimura, Y., Y. Nakamura, T. Oda, H. Yamada, T. Nanno, M. Ando, Y. Ubukata, and M. Suzuki. 1990. Effects of gonadotropin-releasing hormone agonists on meiotic maturation of follicle-enclosed oocytes in rabbits. Biol. Reprod. 43:1012-1018.

19. Yoshimura, Y., Y. Nakamura, T. Oda, M. Ando, Y. Ubukata, N. Koyama, M. Karube, and H. Yamada. 1992. Effects of prolactin on ovarian plasmin generation in the process of ovulation. Biol. Reprod. 46:322-327.

20. Beadwell, C. G. 1971. Radioimmunoassay for arginine vasopressin in human plasma. J. Clin. Endocrinol. Metab. 33:254-260.

21. Morimoto, T., M. Aoyama, E. Gotoh, and H. Shionoiri. 1983. A method of radioimmunoassay of plasma angiotensin II using florisil. Folia Endocrinol. Jpn. 59:215-229.

22. Howard, R. B., A. G. Pucell, F. M. Bumpus, and A. Husain. 1988. Rat ovarian renin: characterization and changes during the estrous cycle. Endocrinology. 123:2331-2340.

23. Fernandez, L. A., B. C. Tarlatzis, P. J. Rzasa, V. J. Caride, N. Laufer, A. F. Negro-Vilar, A. H. DeCherney, and F. Naftolin. 1985. Renin-like activity in ovarian follicular fluid. Fertil. Steril. 44:219-223.

24. Ichikawa, F., Y. Yoshimura, T. Oda, M. Shiraki, K. Maruyama, S. Kawakami, Y. Nakamura, and M. Fukushima. 1990. The effects of lipoxygenase products on progesterone and prostaglandin production by human corpora lutea. $J$. Clin. Endocrinol. Metab. 70:849-855.

25. Ganong, W. F. 1984. The brain renin-angiotensin system. Annu. Rev. Physiol. 46:17-31.

26. Pandey, K. N., M. H. Melner, M. Parmentier, and T. Inagami. 1984. Demonstration of renin activity in purified rat Leydig cells: evidence for the existence of an endogenous inactive (latent) form of enzyme. Endocrinology. 115:1753-1759.

27. Van Sande, M. E., S. L. Scharpe, H. M. Neels, and K. O. Van Camp. 1985. Distribution of angiotensin converting enzyme in human tissues. Clin. Chim. Acta. 147:255-260.

28. Naruse, K., M. Murakoshi, Y. Osamura, M. Naruse, H. Toma, K. Watanabe, H. Demura, T. Inagami, and K. Shizume. 1985. Immunohistological evidence for renin in human endocrine tissues. J. Clin. Endocrinol. Metab. 61:172177.

29. Sealey, J. E., S. A. Atlas, and J. H. Laragh. 1980. Prorenin and other large molecular weight forms of renin. Endocr. Rev. 1:365-391.

30. Yoshimura, Y., R. Santulli, S. J. Atlas, S. Fujii, and E. E. Wallach. 1987 The effects of proteolytic enzymes on in vitro ovulation in the rabbit. Am. J. Obstet. Gynecol. 157:468-475.

31. Yoshimura, Y., K. Maruyama, M. Shiraki, S. Kawakami, M. Fukushima, and Y. Nakamura. 1990. Prolactin inhibits plasminogen activator activity in the preovulatory follicles. Endocrinology. 126:631-636.

32. Daud, A. I., F. M. Bumpus, and A. Husain. 1988. Evidence for selective expression of angiotensin II receptors on atretic follicles in the rat ovary: an autoradiographic study. Endocrinology. 122:2727-2734.

33. Pucell, A. G., F. M. Bumpus, and A. Husain. 1988. Regulation of angiotensin II receptors in cultured rat ovarian granulosa cells by follicle-stimulating hormone and angiotensin II. J. Biol. Chem. 263:11954-11961.

34. Oparil, S. 1983. Angiotensin I converting enzyme inhibitors and analogues of angiotensin II. In Hypertension. Pathophysiology and Treatment. J. Genest, O. Kuchel, P. Hamet, and M. Cantin, editors. McGraw-Hill Inc., New York. pp. 250-270

35. Anderson, P. W., W. B. Malarkey, J. Salk, O. A. Kletsky, and W. A. Hsueh. 1989. The effect of angiotensin-converting enzyme inhibition on prolactin responses in normal and hyperprolactinemic subjects. J. Clin. Endocrinol. Metab. 69:518-522.

36. Ferris, T. F., and E. K. Weir. 1982. Effect of captopril on uterine blood flow and prostaglandin $\mathrm{E}$ synthesis in the pregnant rabbit. J. Clin. Invest. 71:809815 .

37. Daud, A. I., F. M. Bumpus, and A. Husain. 1990. Characterization of angiotensin I-converting enzyme ( $\mathrm{ACE}$ )-containing follicles in the rat ovary during the estrus cycle and effects of ACE inhibitor on ovulation. Endocrinology. 126:2927-2935.

38. Squires, P. M., and T. G. Kennedy. 1992. Evidence for a role for a uterine 
renin-angiotensin system in decidualization in rats. J. Reprod. Fertil. 95:791802 .

39. Velletri, P. A. 1985. Testicular angiotensin I-converting enzyme (E.C. 3.4.15.1). Life Sci. 36:1597-1608.

40. Yoshimura, Y., L. Espey, Y. Hosoi, T. Adachi, S. J. Atlas, R. B. Ghodgaonkar, N. H. Dubin, and E. E. Wallach. 1988. The effects of bradykinin on ovulation and prostaglandin production by the perfused rabbit ovary. Endocrinology. 122:2540-2546.

41. Armstrong, D. T., D. L. Grinwich, Y. S. Moon, and J. Zamecnik. 1974. Inhibition of ovulation in rabbits by intrafollicular injection of indomethacin and prostaglandin F antiserum. Life Sci. 14:129-140.

42. Hamada, Y., K. H. Wright, and E. E. Wallach. 1978. In vitro reversal of indomethacin-blocked ovulation by prostaglandin $\mathrm{F}_{2 \alpha}$. Fertil. Steril. 30:702-706.

43. LeMaire, W. J., M. R. Clark, G. B. N. Chainy, and J. M. Marsh. 1980. The role of prostaglandins in the mechanism of ovulation. In Endocrine P R. I. Tozzni, G. Reeves, and R. L. Pineda, editors. Elsevier/North-Holland, Amsterdam. pp. 207-217.

44. Yoshimura, Y., and E. E. Wallach. 1987. Studies of the mechanism(s) of mammalian ovulation. Fertil. Steril. 47:22-34.
45. Nasjletti, A., and K. U. Malik. 1979. Relationships between the kallikreinkinin and prostaglandin systems. Life Sci. 25:99-110.

46. Whorton, A. R., S. L. Young, J. L. Data, A. Barchowsky, and R. S. Kent 1982. Mechanism of bradykinin-stimulated prostacyclin synthesis in porcine aortic endothelial cells. Biochim. Biophys. Acta. 712:79-87.

47. Vio, C. P., M. M. Bednar, and J. C. McGiff. 1983. Prostaglandins as mediators and modulators of the kallikrein-kinin system. Adv. Exp. Med. Biol. 156:501-514.

48. Sandberg, K., M. Bor, H. Ji, A. Markwick, M. A. Millan, and K. J. Catt 1990. Angiotensin II-induced calcium mobilization in oocytes by signal transfer through gap junctions. Science (Wash. DC) 249:298-301.

49. Cornwallis, C. M., S. L. Skinner, P. L. Nayudu, A. Lopata, R. L. Thatcher, S. P. Yeung, and J. A. Whitworth. 1990. Follicular Fluid renin concentration and IVF outcome. Hum. Reprod. 5:413-417.

50. Itskovitz, J., S. Rubattu, Z. Rosenwaks, H. C. Liu, and J. E. Sealey. 1991 Relationship of follicular fluid prorenin to oocyte maturation, steroid levels, and outcome of in vitro fertilization. J. Clin. Endocrinol. Metab. 72:165-171.

51. Brentjens, J. R., S. Matsuo, G. A. Andres, P. R. B. Caldwell, and L. Zamboni. 1986. Gametes contain angiotensin converting enzyme (kininase II). Experientia (Basel) 42:399-402. 